\title{
APSA Publishes New Book on Civic Engagement Education
}

$\mathrm{F}$ or a democracy to function effectively, its citizens must participate. Furthermore, these same citizens must deliberate effectively, engage with one another, and arrive at workable compromises. Although these skills are critical for a vibrant society, the means to learn and develop them-civic engagement education-is lacking in American education today. Teaching Civic Engagement Across the Disciplines evaluates the goals, challenges, and rewards of integrating civic education into the curriculum, highlighting best practices across disciplines and campuses.

Editors Elizabeth C. Matto, Alison Rios Millett McCartney, Elizabeth A. Bennion, and Dick Simpson have gathered a diverse group of 38 contributors who approach civic engagement education from multiple disciplines and perspectives. The result is a book that is nuanced, far reaching, and practical for all educators. The book explains how campuses can promote high quality education for civic engagement, providing a wealth of examples of successful practices, techniques, and assessment strategies.

The first section lays a foundation for successful civic engagement education, discussing the optimum classroom and campus environment, the government's role in civic education, and the history of civic education, particularly in political science. The next section explores the purpose and practice of civic education as and the importance of integrating such education across the disciplines, including the arts, engineering, and general education. Finally, the last section moves beyond the classroom to explore additional ways to expand civic engagement across the disciplines and throughout campus life. The chapters argue that politics effects every person and profession; therefore, educating students of all disciplines will prepare them to successful engage in their communities throughout their lives and careers.
As democracies and societies become increasingly complex, education for civic engagement becomes ever more critical. It should not be confined to government or civics classes, but should be available to all students in all areas of study. Civic engagement education can provide students with the knowledge, skills, values, and confidence they need to be active, engaged citizens who make a meaningful difference in their communities.

\section{ENDORSEMENTS FOR THE BOOK}

"Any college faculty member or administrator who cares about the future of our country should read this splendid book. In more than two thoughtful dozen essays, the volume focuses not just on learning about how governments work, but, more important, on how students can gain the knowledge, skills, and attributes necessary to be actively engaged in public-policy and politics. These capacities are essential if our democracy is to function as it should. Faculty and administrators in fields across the curriculum and co-curriculum will find practical wisdom about teaching democratic practices."

-Thomas Ehrlich, President Emeritus, Indiana University

"Editors Matto, McCartney, Bennion, and Simpson-along with the authors of the chapters in this volume-make substantial contributions to our understanding of the dynamics of civic engagement across disciplines. Their research is grounded in theoretical innovation and empirical investigation, advancing knowledge about teaching civic engagement well beyond the discipline of political science by providing examples of civic education that reach across departments and programs. It is "must reading" for anyone interested in civic education."

-Jane Junn, Professor of Political Science, University of Southern California

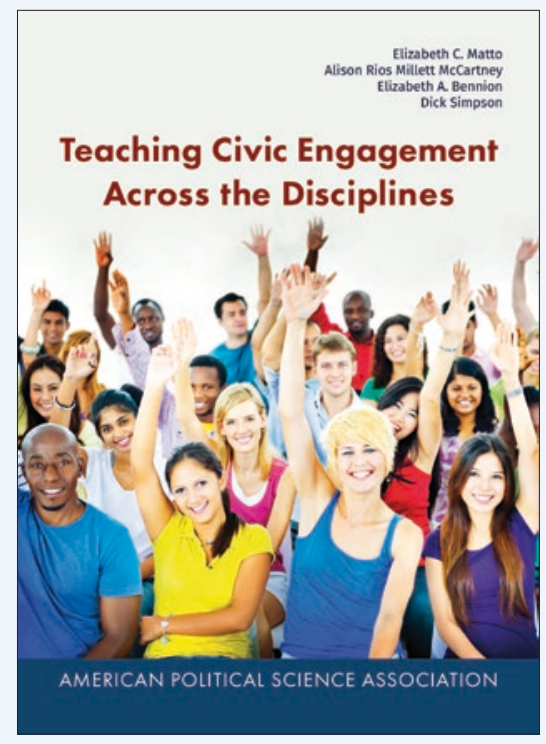

"Teaching Civic Engagement Across the Disciplines, offers a unique approach that is both cross-disciplinary and interdisciplinary evidence for training tomorrow's citizenry. By providing the theory, practice and tools to faculty who want to involve students in their communities and beyond, this edited volume recommends techniques, such as institutional programming, faculty development, and interdisciplinary opportunities for involving students in their social and political world. As a genuine contribution to the field of civic engagement, Teaching Civic Engagement Across the Disciplines should be in every institution of higher education's library."

-Bobbi Gentry, Assistant Professor of Political Science, Bridgewater College

\section{COMPANION WEBSITE}

Along with the book, APSA and the editors have built a companion website with supplementary materials from the book as well as a free ebook version! The website will provide an ongoing resource for educators dedicated to civic engagement education. The site can be found at www.apsanet.org/tce2. 


\section{TOP TEN REASONS TO BE AN APSA MEMBER.}

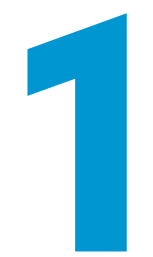

Increase your professional visibility

\& stay connected to 12,000

political science professionals.

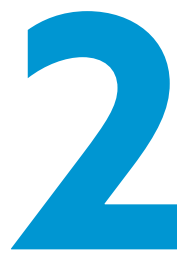

Stay up-to-date on the latest research in political science with access to APSA's three leading peer-reviewed political science journals.

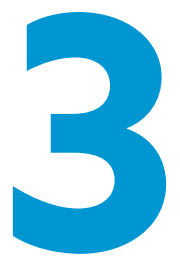

Search the latest job openings using APSA eJobs, the most comprehensive database of jobs related to political science. Browse the newest listings and upload your resume today!

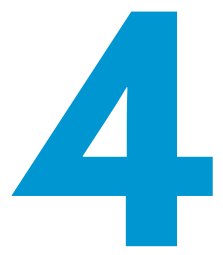

Engage with your colleagues interested in similar subfields of political science by joining an APSA Organized Section.

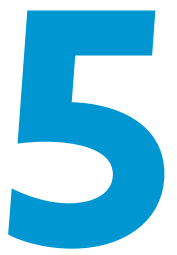

Enjoy member-only discounts of up to $46 \%$ off the registration fee for the APSA Annual Meeting and APSA Teaching \& Learning Conference.

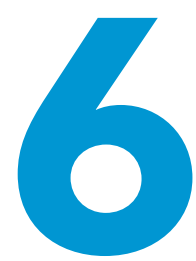

Get professional development advice \& support from experienced \& senior members of the profession through the APSA Mentoring Program.

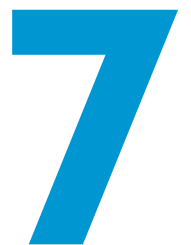

Get your research funded through one of the APSA Centennial Center's programs or by applying for a small research grant!

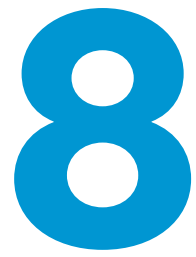

APSA recognizes excellence in the profession by awarding members for outstanding dissertations, papers, articles, \& books in various subfields of the discipline.

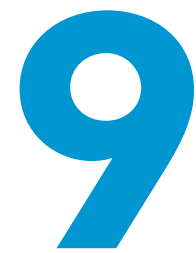

Apply for the Congressional Fellowship Program, a unique \& highly-selective non-partisan program devoted to expanding knowledge \& awareness of Congress.

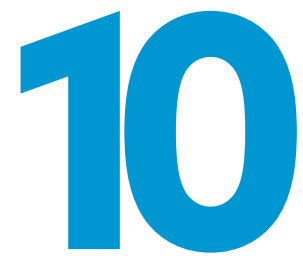

Get involved in one of APSA's International Programs designed to promote closer interaction between American and non-American political scientists. 


\section{lapsa

